InterAcão

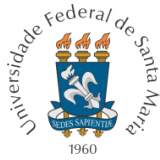

Vol. 11, $\mathrm{n}^{0} 02$, Jul/Dez 2020

\title{
DossIê
}

História Cultural e Imaginário

Ocidental sobre o Oriente

Nurcan Ceyhan ${ }^{1}$

\section{THE CONSTRUCTION OF "THE OTHER": THE RIGHT-WING POPULISM IN EUROPE AND ITS FUNCTIONAL OTHER IMAGE}

\section{A CONSTRUÇÃO DO "OUTRO": O POPULISMO DE DIREITA NA EUROPA E SUA OUTRA IMAGEM FUNCIONAL}

\begin{abstract}
:
This paper examines what other image is and how it is functionally used to construct social realities. It mainly focuses on the other perception of the West and how this perception dominates over politics present-day. In this perspective, it draws attention to populism and its right-wing version which is considered one of the most important and controversial political phenomena of the 21st century. It aims to show how the current right-wing populist parties and politicians in Europe describe and point out their non-Western parts as others and how their way of politics based on the marginalization of these others leads them to get electoral success.
\end{abstract}

Keywords: Other Image; Constructivism; Populism; Right-wing; Europe

\section{RESUMO:}

Este artigo examina o que é a imagem do outro e como ela é funcionalmente usada para construir realidades sociais. Foca principalmente na percepção sobre o outro no Ocidente, e como essa representação domina a política atual. Nessa perspectiva, chama a atenção para o populismo e sua versão de direita que é considerada um dos fenômenos políticos mais importantes e controversos do século 21 . O artigo tem como objetivo mostrar como os atuais partidos e políticos populistas de direita na Europa descrevem e apontam seus homônimos não ocidentais como outros, e como sua forma de política baseada na marginalização desses outros os leva a obter sucesso eleitoral.

Palavras-chave: Imagem do Outro; Construtivismo; Populismo; Extrema-direita; Europa

\section{INTRODUCTION}

The perceptions, representations and stereotypes of the "other image" always get involved in the construction of the social meanings. While a group of people defines themselves, they tend to draw borders and use the image of others immediately. They put the other in a different status, attribute several qualifications to both themselves and the others and construct artificial borders between each other. In this process of social construction, the negative representations of the other are mainly put forward and the meaning is constructed relatively (HALLa, 1997).
The other-oriented discources are prevalent in today's right-wing populism as well. Although populism is considered as the current political style throughout the world, its reflections in European countries have come to the forefront recently. Whereas the right-wing populist parties are also seen as "others" of the mainstream ones in the political spectrum, they always point at "the other inside of the society" to get electoral success. And this recently stands out as an interesting field of study in social sciences. Regarding this issue, it is claimed in this paper that the right-wing

\footnotetext{
1 Ph.D Candidate at Istanbul University - ceyhannurcann@gmail.com - iD https://orcid.org/0000-0002-9087-6780
} 
populist parties and politicians became successful using other images effectively.

This descriptive paper addresses the current rise of populist parties and politicians. Considering the paper's volume and scope, the content analysis method is preferred to use. It is argued that the mainstream political parties and politicians are no longer seen efficient to respond to the existing cultural and socio-economic anxieties of the societies in the eyes of the people and the populist way of politics is rising and seen as an alternative in such an environment. In this context, it is aimed to show how they appeal to the voters and get electoral support using the other images. In an attempt to delimit the subject and to emphasize the "other image" both ideological and geographical distinctions are made. This paper focuses on right-wing populism in several European countries. To point out their current electoral success based on the other images, the several political elections held between 2017 and 2019 in Europe are highlighted. In this regard, the right-wing populist parties and the politicians in France, Italy, Germany, Austria, the Netherlands and Hungary are examined. And it is aimed to show how they reach electoral success by focusing on their political approaches, discourses and election results.

\section{CONSTRUCTING SOCIAL REALITIES: SELF - OTHER DICHOTOMY AND THE OTHERS OF THE WEST}

In today's world, most social scientists agree on that social and collective meanings, realities, representations or structures are formed through certain common thoughts, values and norms. This means that anything with a social dimension is not constant, given and fixed; it is constructed in mutual relations socially and dialogically (PHILLIPS, 2007). In this process of construction, the meaning is neither formed objectively. Many elements such as actors, discourses, thoughts, ste- reotypes and visual determinants play an active role in it. Given that it does not deny the existence of substances in social life, this is what the constructivist theory says as well. In a word, if people are involved in something social, they always construct that. Even their beings are constructed, because their existence has a social dimension (ONUF, 1989).

The construction process of the social realities is directly related to language and discourses and the meaning is shaped by them firstly. Especially the usage of language constructs the meaning itself and enables abstract thoughts to get concrete and alive, so to say come to life and represents them in the social structure. So meanings are produced by representing abstract things in words, allowing us to name things and concepts shaped in our thoughts. These meanings also become collective and cultural ones. Because people living in the same community and cultural context think about a particular phenomenon, interpret and share it in the same way. And this sameness becomes more than just the sum of shared shallow thoughts in individuals' minds in the course of time. They turn into public phenomena (HALLa, 1997).

Most of the social meanings in which the cultural and historical contexts are decisive are shaped in a dichotomic way such as opposite concepts (us versus them, self/me versus others, etc.). Even in Hegelian philosophy, while self and selfconsciousness are being built, another self that is interacting with the self within the social structure is needed (HEGEL, 2003). Hegel embodies this argument in the master and slave relationship. In this process called "struggle for recognition", the nature of the relationship between the slave and the master is essentially dependent on both sides. It means that the slave finds its meaning and reality outside, constructs himself/herself in the master's self (KAIN, 2005).

Dichotomic pairs and the existence of an "other image" are so important while constructing social meanings. Because these concepts point out

\footnotetext{
2 The expression of "other" in this paper means a group of people who is different culturally, religiously, ethnically, linguistically, etc. from Western societies. Here the concept was written in parentheses, but it was generally preferred to write without parentheses the rest of the paper, except for emphasis.
} 
symbolic borders; make the construction of meaning, drawing the imaginary and symbolic lines much easier. These opposite concepts have representative characteristics and they interact or change each other to construct a social reality all the time. Furthermore, these allow us constructing certain stereotypes to describe dichotomic pairs much apparently. Hall expresses this formation in the following paragraph quite clearly:

Stereotyping in other words is a part of the maintenance of social and symbolic order. It sets up a symbolic frontier between the 'normal' and the'deviant' the 'normal' and the 'pathological' the 'acceptable' and the 'unacceptable' what 'belongs' and what does not or is 'Other' between 'insiders' and 'outsiders', Us and Them. It facilitates the 'binding' or bonding together of all of Us who are 'normal' into one 'imagined community'; and it sends into symbolic exile all of Them 'the Others'- who are in some way different'beyond the pale' (HALLb, 1997; 258).

These dichotomies have been shaped by symbolic lines and become collective, cultural and social identities over time. In the process of drawing borders, demarcating between two different things and constructing meanings "the pessimist images of the other" are predominantly taken into account. And the social context in which people live and interact with each other affects it too. The two sides' interaction is especially important. Because it does not make much sense, if the other does not interact with the self and stand in a place away from the self. In this process, for example, while "me/self" adopts a certain role identity, it gives "other" the opposite role that makes its identity meaningful (HALLb, 1997). Wendt also explains it by embodying in some metaphors:

One cannot be a trader without someone to trade with, a proselytizer without a convert, or a conqueror without a conquest. In situations where knowledge is shared, representations of Alter will often correspond to how Alter repre- sents himself, allowing interaction to proceed relatively smoothly (WENDT, 1999; 329) ${ }^{3}$.

As Wendt says, there is another important concept called "collective memory". Common beliefs, thoughts and value judgments of societies are all engraved in this collective memory. It enables a nation, society or a group of people to construct themselves, draw their borders between them and others, show how to interact with outsiders. These are not just simple beliefs or thoughts shared by a small group of people. They are transferred between generations and are a part of the socialization process in the same nation or a society. The representations, dichotomic pairs or the images of the others can also change. But the collective meaning still stays the same as long as the members of that society see them as valuable and important for themselves (WENDT, 1999).

When the arguments so far are examined in a broad and concrete context, -considering the historical examples- it is seen that one of the most important dichotomic pairs showed a geographical characteristic is the East/Orient - West dichotomy. There is even academic literature based on this conceptualization which is called Orientalism ${ }^{4}$. Originally these geographical terms are based on artificial borders between Orient and the West and they are constructed in the social structure. Here, Orient and West correspond to certain kinds of cultural and political structures and as a social reality, their initial construction process dates back to many years ago. Since then, both Orient and West have been associated with a set of stereotypes, cultural and ethical forms, identities, nations, even races and skin colors (SAID, 1979).

As aforementioned earlier, social realities and notions are not fixed and stable. So Orient and West also vary within different periods. Even though it's not linear, certain images, stereotypes and representations have become dominant and come forward all along the Orient-West encountering (KALIN, 2016). This paper sustains that what is linear is that there has always been an other image

\footnotetext{
3 Wendt originally uses the terms of Ego and Alter Ego here.

4 To ensure conceptual integrity, Orient was used throughout this paper, instead of the East.
} 
in their relationship and this argument is valid for both West and Orient. West also represents the other in the eyes of the Orient. Here, because it is pointed out that Orient is a constructed reality according to stereotypes and perceptions of the West, it will be focused on how Orient and its representations are constructed.

Said says that the Orient is a constructed reality by Europe ${ }^{5}$. Not just Orient, the West has also been constructed based on what other is in the eyes of the West. Another point, as a notion both West and Orient have no stability ontologically and haven't been described objectively either. In Said's words:

\begin{abstract}
Orientalism is a style of thought based upon an ontological and epistemological distinction made between 'the Orient' and (most of the time) 'the Occident' (West)... The Orient is not only adjacent to Europe; it is also the place of Europe's greatest and richest and oldest colonies, the source of its civilizations and languages, its cultural contestant, and one of its deepest and most recurring images of the Other (SAID, 1979; 1-2).
\end{abstract}

So, what has been known as Orient for centuries, corresponds to a fictional reality emerged after Europe's definition for itself as a result of its Eurocentric geographical perception (KALIN, 2016).

Who or what are these others and how were they constructed? To answer this question, it is needed to draw attention to how two selves came across and how they were represented historically. The different communities and collective identities have represented the other images for the West within different periods. And whenever they confront and interact with each other, they have begun to construct their meanings as Hegel says "dialectically". Historically, different groups such as Persians, Jews, Muslims, Arabs or colonized societies, immigrants, minorities, blacks, Asians, etc. have been constructed as other (KALIN, 2016). When it comes to the Orient, Arabs and Islam have represented it for about a thousand years (SAID,
1979). Until Enlightenment, Orientalist discourses and constructed other images were led by Christianity; it was religious-oriented, derived from Islam Christianity dichotomy (ZEBIRI, 2011). Accordingly, the Orientalists were students of Semitic languages and sacred book researchers until the middle of the 18th century (SAID, 1979).

After the 18th century, Orientalism started becoming a philology-oriented field. The Orient happened to have a discoursive meaning which is unequal with the West (SAID, 1979). Islam was examined by Orientalism in the following periods, assumed the anti-thesis of the West; Muslims began to be seen as violent, uncivilized existences in essence (BEYDOUN, 2016). In recent history, culturally and sociologically different people who belong to old colonized societies or -as it was seen in the late 20th century- ideologically different countries or societies became a part of the other image in the eyes of the West.

No matter how it is conceptualized, here it is argued that there has been a certain concrete distance between the others and the West for a long time. These two sides had encountered in certain situations such as war and at certain times; had sharp boundaries. But especially since the second half of the 20th century, the nature of the relationship between these two sides began to change. Others turned into a close part of the West. Many factors such as the decolonization process, immigration and globalization brought this result. The other of the past turned into an other inside of the West. And the West began to be heterogeneous sociologically, had to absorb the non-Western components. The most important point here is that these new parts of the West belong to one of the most prominent other images of the West. They have been coming from old colonies of the West and have had bonds with Islam religiously and culturally. Thus, they have shown linear characteristics as others.

In the final stages of the meaning construction process of two sides (since the 1980s), several

\footnotetext{
${ }^{5}$ It should be noted that because of the Eurocentric perspective of that time, generally the concept of "Europe" was used. When the lines of the concept of Europe expanded and comprised the other parts of the West, Europe turned into the West and the West began to be used instead of Europe.
} 
academic papers divided the world into various civilizational parts and argued that some parts are uncompromising with others (another method of marginalization) (HUNTINGTON, 1996) or claimed that "The End of the History" and the West's moral, ideological, cultural victory (FUKUYAMA, 1992) have also contributed to this process negatively. On the other hand, Western societies have become more heterogeneous gradually in such an environment, produced new discriminatory forms and phobias such as racism, xenophobia, Islamophobia to marginalize "others". Furthermore, several negative national and international incidents -such as 9/11- have been involved in the interactions of two sides and the construction of the meanings for each other as well. So the characteristics of the relationship between others and self have begun to gain a quite different dimension. As it is seen, the other image kept itself alive somehow.

Consequently, the concept of the other and the social realities based on this concept are always immanent in social life. Even though the notions and components of the constructed realities change sometimes, the general reasoning about why the meaning is based on the other notion doesn't change. When these others are used functionally to achieve political success, then things begin to get much worse for the heterogeneous societies.

\section{POPULISM AND POPULIST OTHER IMAGES}

The discriminatory attitudes, behaviors and perceptions based on the other images have become the basic dynamics of the 21st century. In a similar vein and as this paper detects, the debate on the other images in social science has come to the fore with the rise of populism recently. Although it is not a new concept, populism is one of the most controversial political phenomena of recent years. It has been historically associated with fascism, but while populism is a type of authoritarian democracy, fascism is a dictatorial rule, not a democratic regime. These two concepts are just genealogically related to each other and there is no regime type such as elective dictatorship (FINCHELSTEIN, 2019). So, it is argued here that modern populism is a newly constructed phenomenon as well. It adapts itself into different ideologies and regime types whether it is democratic or authoritarian in today's world.

The notion of populism is generally used to express the current crisis of democracies, the new authoritarianism arguments or as Zakaria says "illiberalism" debate (ZAKARIA, 1997). While on one hand it is argued that populism is a democratizing response to the crisis of representative democracy, on the other hand, it is claimed that populism sets non-democratic boundaries to the future of democracy (FINCHELSTEIN, 2019). In general, populism addresses three main themes; an ideology, a form of politics that provides political mobilization and a political discourse (MOFFITT, 2017). But it is mostly associated with the current crisis of liberal democracy. In this perspective, a distinction is made between democracy and liberal democracy and today's understanding of democracy is increasingly reduced to the Schumpeterian understanding of democracy. Thus, democracy is seen as just a simple election process that is free from liberal values (SCHUMPETER, 2006). This problematic understanding of democracy is also a starting point of modern populism today.

In general, populism is the name of a form of politics that is against plural society, political elites and political establishment. It considers society as a homogeneous group, not a heterogeneous one. That's why populists construct a polarized society and benefit from the general problems of it using democratic methods to come to power. While liberalism accepts that there are multiple groups in society, populism divides the society into two main parts as elites and real people; liberalism aims for the consensus of the different views, populism on the other hand disregards them and pursues hostile, contentious policies (PAPPAS, 2016).

Populism has a paradoxical relationship with democracy. To come to power and to achieve electoral success, populists play the game by its rules. They act within the boundaries of democracy and claim to be a manifestation of the popular will. However, they ignore the most basic elements of the liberal democracy -such as rule of 
law, protecting minority rights, etc.- and use a polarising and discriminatory discourse (KRASTEV, 2007). Thus populist mentality acts within the boundaries of democracy but it is against the basic values of liberal democracy. That's why the type of relationship between populism and democracy is quite complex and intertwined. Arditi associates populism with a drunken guest and illustrates the nature of the relationship between populism and democracy in this metaphor as follows:

\begin{abstract}
...an analogy with the discomfort caused by the arrival of a drunken guest at a dinner party. He is bound to disrupt table manners and the tacit rules of sociability by speaking loudly, interrupting the conversations of others, and perhaps flirting with the wives of other guests. The hosts might not be particularly happy with the awkward visitor, but having invited him they probably cannot get rid of him either, so they will do their best to downplay his antics in order to make the rest feel as comfortable as possible (ARDITI, 2005, 90-91).
\end{abstract}

The most distinctive characteristic of populism is its image of society. In this perspective, Mudde sees populism "as an ideology that considers society to be ultimately separated into two homogeneous and antagonistic groups, 'the pure people' versus 'the corrupt elite', and which argues that politics should be an expression of the volonté générale (general will) of the people" (MUDDE, $2004 ; 543$ ). Anyone might speak in the name of socalled "pure/real people". But the populist version of them claims that only they have this right and do it in the representative democratic systems properly. They have a horizontal relationship with people and act like they are one of them and real representative of the people. So "...in addition to being anti-elitist, populists are always antipluralist: populists claim that they, and only they, represent the people" (MULLER, 2016).

As it is seen, the perception of the other is also involved in populism. Although populist "others" are seen as corrupt elites at first sight, the concept of the "pure people" is not seen as very homogeneous either. It is claimed in this paper that another "others" also come to the fore among the pure people perception of populism. It constructs its own symbolic "real people image". While the right-wing populists frequently use this discourse, The left-wing populism on the other hand adopts less discriminatory approaches when it is compared with the right-wing populism. The main distinction between the left and the rightwing populism arises in the context of who they exclude and it is shaped by their ideologies. So the ideology that populism is related also affects the construction of others (MUDDE, 2015). For example, while the left-wing populism in Latin America is an inclusive ideal in recent years and it usually brings together different ethnic identities in a common political framework; the right-wing populism targets and excludes the immigrants and minorities (who are seen as "others") predominantly (GIDRON; BONIKOWSKI, 2013). Besides several right-wing populists behave selectively towards others, include certain groups (e.g. women or homosexuals) to their own "people" perception but targets a specific other such as minorities or immigrants (MOFFITT, 2017).

While the West is always envisioned as a real home of liberal democracy, the general political situation of Western countries in recent years shows that this assumption appears to be no longer valid. In a sense, this means that the West moves away from its own values (ZAKARIA, 1997). Here it is claimed that -whether a pathology or a temporary crisis of liberal democracies- the populism uses the other images quite functionally. The populist mentality sees the others of the "real people" as scapegoats of the anxieties caused by the socio-economic, cultural and political problems. They are perceived differently in every aspect and are useful targets for populists to attract the restless masses and get electoral success.

\section{THE RIGHT-WING POPULISM IN EUROPE AND ITS OTHERS}

The populist -especially the right-wing populist- parties and politicians are getting attention from Brazil to India, from Poland to the Philippines 
around the world. Since 2016, along with the Brexit process in the UK and the presidential elections in the USA, the concept of populism has begun to appeal to people and is being used increasingly (ROODUIJN, 2018). The populism must be perceived as an expression of dissatisfaction with mainstream politicians or political establishment rather than an attack on the democratic system. Because populist voters tend to support the existing democratic system and its values, but they think that it is no longer as functional as it should be. Thus, they support populist parties and politicians whether they are political outsiders or the ones coming out of the political establishment itself. The populists know how to problematize and take advantage of certain incidents in the national and international context which make people worried about themselves and their future and place them in the center of politics. In this way, people move away from the traditional way of politics and see the new form of politics as an alternative (MOUFFE, 2005).

It is worth noting that, even though populism is accepted as a political style of political outsiders, the mainstream politicians seen as a part of the political establishment also incline to the populist style of politics. Because they are well aware of potential effects of the populism on the political arena. And this makes mainstream politics and politicians change and radicalize as well. Though populism is identified with any ideology, the rightwing version of it is mostly adopted in recent years. Considering the right-wing populist parties and politicians in Europe, it is seen that they maintain a nativist, nationalist stance in both domestic and international politics. They are anti-elitist and antiestablishment, mainly target immigrants and minorities; their discourses have discriminatory characteristics based on the marginalization of the others (MUDDE, 2015; COLLOT, 2017). Particularly with the latest immigration waves as a result of spillover effects of the certain international incidents such as the Syrian Civil War, the immigration issue begins to become prominent in populist discourses. And this shows how other images are used by populism and influence politics as well.
It is asserted here that European societies are no longer pure, homogeneous at present. Their social fabric began to undergo changes and got a heterogeneous characteristic long ago. The minorities, immigrants or other groups of people who are different culturally, ethnically, linguistically, religiously are part of these societies now and they continue to be. The main argument here -as in the self's interaction with others- emerges from the incompatible characteristics of the "other" envisioned in the self's definition. This perception is also substantiated with certain incidents causing negative effects on the relationship between these two sides. And these are consistently used in political discourses. Especially in an atmosphere in which social anxieties, economic problems and crisis influence throughout society, such a form of politics becomes successful and the concrete examples of these arguments are seen all around Europe.

Focusing on several examples of populist actors and parties across Europe, it is concluded that populists consider existing social and economic crisis, cultural differences as a good opportunity for themselves all around the continent. In this respect, the most prominent cases are seen in Italy and countries like Hungary in Eastern Europe. In terms of "other images" and how they are used by right-wing populists, Hungary is pointed out firstly. Hungary began to use nationalist, antiimmigrant discourses and sentiments more effectively along with the right-wing populist Fidesz Party's administration. The migration policies were reformed and these marginalized others began to be seen as a national threat and even wire fences were used for drawing concrete lines between others and the real people. The immigrants were seen as a matter of life and death, even prime minister Orbán called people to defend their countries against these others (GOŹDZIAK, 2019). During the 2018 general elections, Orbán re-elected for his third term as a prime minister. Along with the election campaign, he stuck by his nationalist, predominantly immigrant oriented populist policies and discourses. His Fidesz Party almost won 50\% of the votes and this result showed that Fidesz and 
his leader Orbán became electorally successful with their right-wing populist style based on others (BBC.com, 2018).

In Italy, the latest general election results also presented the great success of populist parties in 2018 . The Five Star Movement and the League had a big role in this success. While Salvini's League is nationalist and shows a total right-wing feature, the Five Star Movement can be described as just populist and antiestablishment; neither complete right-wing nor leftwing. Forza Italia should also be mentioned as another populist actor that represents the center-right of the political spectrum in Italy. These three parties came to the fore in the 2018 general elections and determined the course of events in politics in Italy lately. Though the changes were observed in the attitudes and actions of these parties after the election period, their populist way of politics generally made them successful. And this success was derived from the general effects of the financial crisis as well as their nationalist stance and discourses against the European Union, the immigrant issue and social problems across the country. Especially it should be noted that the immigrants were highlighted as others predominantly in the election campaigns and are still assumed to be the main target by the League Party (D'ALIMONTE, 2019).

The leading actors of the right-wing populist trend in Germany are AfD -Alternative for Germany- and PEGIDA corresponded with "Patriotic Europeans Against the Islamisation of the Occident". While AfD is a political party, claiming to be the epitome of "the people" and anti-immigrant; PEGIDA is a movement that shows nationalist, discriminatory characteristics and effects on mobilizing restless masses. Both of them have been getting support based on their nationalist-populist approaches and discourses. In this perspective, the AfD as a rising right-wing populist political party is seen as a significant example. It got $12.6 \%$ of the general votes and entered the parliament for the first time in 2017 (BUNDESWAHLLEITER.de, 2017) and got $11 \%$ of the votes in European Parliament Elections in 2019 (EUROPARL.EUROPA.eu, 2019). These results represent a great success for AfD and show how it mobilizes people, has a voice the "problems of the people" and gets electoral sup- port using other images. The highest priority of the AfD is to prevent and to stop the migration in Germany and it is completely against the current immigration policies of the government. Considering the AfD's ultra-nationalist envisagement towards German society it is seen that not just immigrants, the foreigners are not welcomed by AfD either (MACGREGOR, 2019).

France's famous National Rally -formerly known as the National Front- is another right-wing populist party that conducts a successful policy on its behalf. Even though the leader of the party Marine Le Pen lost against Emmanuel Macron in the presidential elections in 2017, she and her party increased their votes and became successful in their way. She ran a successful campaign against immigration and the European Union, as it was seen from the discourses of other right-wing populist parties in Europe as well (BBC.com, 2019). During the election campaigns and rallies, she emphasized that France is the home of French people, the immigrants should be expelled to their own home and to "make France 'more French' " (NOSSITER, 2017). It is clearly seen that Le Pen's discourses were really effective on voters and made her emerge as one of the two final candidates in the presidential elections. If Le Pen goes on what she has been doing, mobilizing people using the other images, she might be successful on her behalf in the next elections planned to be held in 2022.

Another one that reached electoral success thanks to the immigrant crisis and marginalization of the others is Austria's Freedom Party (FPÖ). Along with the general elections in 2017, the nationalist, conservative, anti-immigrant, right-wing populist Freedom Party became the third party getting almost $27 \%$ of the votes and a coalition partner of the Austrian People's Party (ÖVP). While the ÖVP shows conservative and liberal characteristics, it also adheres to policies focused on immigration and immigrants as its right-wing coalition partner does. Although the political tendency in Italy goes parallel with Austria, it stands on the margins of right-wing politics but goes on with the populist political form (BBC.com, 2019). The populist parties use the other images on their political discourses in both countries eloquently, but other- 
oriented populist politics mostly dominates the political arena in Austria. In 2019, it was also seen that the political success of the FPÖ was eroded relatively. A snap election was held in Austria, and FPÖ experienced a decline in its electoral success that it reached in 2017. The reason for FPÖ's decline in 2019 was mostly ascribed to the corruption scandals and the decreasing of highlighting of immigration issues on its discourses. But, regardless of FPÖ's loss, it got considerable support and achieved to get third place in snap elections (DRAŽANOVÁ, 2019).

Europe's other controversial and featured actor of the right-wing populism is Party for Freedom in the Netherlands. Geert Wilders' Party for Freedom is a prime example of the right-wing populist parties in Europe and the basic themes of the populist "other image" such as anti-immigrant, anti-Islam and nationalist stance are the ones Wilders has used all the time. Especially Wilders' attitudes, discourses and actions towards Islam helped him to construct the basic structure of Islamophobia in the Netherlands (BBC.com, 2011). In the 2017 general elections, though his party was in second place and failed to come as first-party, his aggressive and polarizing style of politics made him get $13 \%$ of the votes and won 20 seats in the House of Representatives. This result shows that his extreme right-wing political style has had a significant influence on politics in Dutch politics (BBC.com, 2017).

It is clearly seen that the impact of rightwing populist parties in European politics is remarkably rising. Their success in some cases shows how they use social anxieties functionally and turn them into electoral success on their behalf so easily. Even though there have been other cases about populism such as its left-wing versions in Spain and Greece, the effects of the left-wing populism haven't taken long. They don't focus on marginalizing "others", their basic interests have economical features (MUDDE, 2015). But when it comes to right-wing ones, their influence doesn't seem to diminish in the short term. As long as they go on to adhere to discriminatory politics, mobilizing people, using "other images", socio-economic issues, cultural differences; they seem to shape political structure deeply.

\section{CONCLUSION}

Dichotomic notions and the "other images" that emerge from this conceptualization are always used while constructing social meanings and realities in every moment of social life. Historically one of the most important other images can be seen in the Orient - West dichotomy. The distinction between these two concepts means more than being a geographical term, they are dialogically constructed structures based on cultural and political perceptions, stereotypes and representations. When it is viewed through the eyes of the West, Orient has always been an old enemy in the battlefield, an opponent who is different religiously, a colonized country by the West until the 19th century or an incompatible "other" inside of the West.

While Orient has been constructed, generally the pessimistic images of the other have been considered and this reasoning is adopted all the time. The projection of this perception is also seen on the right-wing populist parties and their functional "other" image. The way of politics of current populist parties and politicians -especially its rightwing versions- across the world shows that constructing other images based on marginalizing a group of people by using the socio-economic crisis and the anxieties of society is an effective way for electoral success. This perception is adopted by several European right-wing populist parties and politicians and they put forward the immigrants as their other predominantly.

It is seen that the current success of the right-wing populist parties and politicians in Europe is related to their functional other image and how well they use these others. They have always pointed out immigrants as the other of the Western societies and the underlying cause of the economic and other social problems in European societies. While the general logic of populism is to split the society into two parts in essence as "real people" and the "corrupt elites", its European rightwing versions split real people into another two 
parts; "others of the real people" versus "the real people". And for the right-wing populist parties, the immigrants represent this second type of the others. They have always used these others functionally to provide social mobilization and get political support. In this perspective, they have succeeded in politics so far.

\section{REFERENCES}

ARDITI, B. Populism as an Internal Periphery of Democratic Politics. In: PANIZZA, Francisco (Org.) Populism and the Mirror of Democracy. London: Verso, 2015, p. 72-98.

BBC.com. Netherlands Islam Freedom: Profile of Geert Wilders. 2011. Available in: https:// www.bbc.com/news/world-europe-11443211. Access: 10 July. 2020.

BBC.com. Dutch Election: Wilders Defeat Celebrated by PM Rutte. 2017. Available in: https:// www.bbc.com/news/world-europe-39287689. Access: 10 July. 2020.

BBC.com. Viktor Orban: Hungary PM Re-elected for Third Term. 2018. Available in: https:// www.bbc.com/news/world-europe-43693663. Access: 10 July. 2020.

\section{BBC.com. Europe and Right-wing Nationalism: A} Country-by-country Guide. 2019. Available in: https://www.bbc.com/news/world-europe36130006. Access: 10 July. 2020.

BEYDOUN, K. A. Islamophobia: Toward A Legal Definition and Framework. Columbia Law Review Online, vol.116, November 1, 2016 p.108-125. Available in: https://columbialawreview.org/ content/islamophobia-toward-a-legal-definitionand-framework/, Access: 10 July.2020.

BUNDESWAHLLEITER.de. Bundestag Election 2017. 2017. Available in: https://www.bundeswahlleiter.de/ en/bundestagswahlen/2017/ergebnisse/bund99.html Access: 10 July. 2020.
COLLOT, G. Understanding Far Right Populism: Interview with Caterina Froio. Oxford Internet Institute. 2017. Available in: http:// www.theneweuropean.eu/open-society/ understanding-far-right-populism-interview-withcaterina-froio-oxford-internet-institute. Access: 10 July. 2020.

D'AlIMONTE, R. How the Populists Won in Italy. Journal of Democracy. vol.30, no.1, 2019, p.114-27.

DRAŽANOVÁ, L. Austria's Snap Election: Why Has the Far-right Freedom Party Suffered Such Heavy Losses?. 2019. Available in: https:// www.sv.uio.no/c-rex/english/news-and-events/ right-now/2019/2019_10_austria-election.html. Access: 10 July. 2020.

\section{EUROPARL.EUROPA.eu. 2019 European Election}

Results. 2019. Available in: https:// europarl.europa.eu/election-results-2019/en/ national-results/germany/2019-2024/. Access: 10 July. 2020.

FEDERICO, F. Faşizmden Populizme. İstanbul: İletişim Yayınları, 2019.

FUKUYAMA, F. The End of History?. The National Interest, vol.16, 1989, p.3-18. Available in: www.jstor.org/ stable/24027184, Access: 10 July, 2020.

GOŹDZIAK, E. M. Using Fear of the "Other," Orbán Reshapes Migration Policy in a Hungary Built on Cultural Diversity. 2019. Available in: https:// www.migrationpolicy.org/article/orban-reshapesmigration-policy-hungary\#. Access: 10 July. 2020.

HALLa, S. The Work of Representation. In: HALL, Stuart (Org.) Representation: Cultural Representations and Signifying Practises. Sage Publications, 1997, p.15-75.

HALLb, S. The Spectacle Of The "Other". In: HALL, Stuart (Org.) Representation: Cultural Representations and Signifying Practises. Sage Publications, 1997, p. 223-291. 
HEGEL, G.W.F. The Phenomenology of Mind. Mineola: Dover Publications, 2003.

HUNTINGTON, S.P. The Clash of Civilizations and The Remaking of World Order. New York: Simon and Schuster, 1996.

KAIN, P.J. Hegel and the Other: A Study of the Phenomenology of Spirit. New York: State University of New York Press, 2005.

KALIN, İ. Ben Öteki ve Ötesi: İslam-Bat İlişkileri Tarihine Giriş. 6. Baskı. İstanbul: İnsan Yayınları, 2016.

KRASTEV, I. Is East-Central Europe Backsliding? The Strange Death of the Liberal Consensus. Journal of Democracy, vol.18, no.4, 2007, p.56-63.

MACGREGOR, M. A Plan to Stop Immigration: Germany's AfD Party. 2019. Available in: https:// www.infomigrants.net/en/post/17960/a-plan-tostop-immigration-germany-s-afd-party Access: 10 July. 2020.

MOFFITT, B. Liberal Illiberalism? The Reshaping of the Contemporary Populist Radical Right in Northern Europe. Politics and Governance, vol.5, no.4, 2017, p. 113. Available in: https://

www.cogitatiopress.com/politicsandgovernance/ article/view/996. Access: 10 July.2020.

MOUFFE, C. On The Political. Routledge, 2005.

MUDDE, C. The Populist Zeitgeist. Government and Opposition, vol.39, 2004, p.541-563.

MUDDE, C. The Problem with Populism. 2015. Available in: https://www.theguardian.com/ commentisfree/2015/feb/17/problem-populism-syriza -podemos-dark-side-europe. Access: 10 July. 2020.

MULLER, J. What is Populism? University of Pennsylvania Press, 2016.

NOAM, G.; BONIKOWSKI, N. Varieties of Populism: Literature Review and Research Agenda. Weatherhead Working Paper Series, no.4, 2013. Available in: https://scholar.harvard.edu/gidron/ publications/varieties-populism-literature-reviewand-research-agenda. Access:10 July. 2020.

NOSSITER, A. Marine Le Pen Leads Far-Right Fight to Make France 'More French'. 2017. Available in: https://www.nytimes.com/2017/04/20/world/ europe/france-election-marine-le-pen.html. Access:10 July. 2020.

ONUF, N. G. Word of Our Making: Rules and Rule in Social Theory and International Relations. University of South Carolina Press, 1989.

PAPPAS, T.S. Modern Populism: Research Advances, Conceptual and Methodological Pitfalls and the Minimal Definitions. Oxford Research Encyclopedia of Politics, 2016.

PHILLIPS, A. B. Constructivism. In: GRIFFITS, M. (Org.) International Relations Theory for the Twenty-First Century. Routledge, 2007, p.60-75.

ROODUIJN, M. Why is Populism Suddenly All the Rage?. 2018. Available in: https:// www.theguardian.com/world/politicalscience/2018/nov/20/why-is-populism-suddenly-so -sexy-the-reasons-are-many. Access: 10 July 2020.

SAID, E. W. Orientalism. New York: Vintage Books, 1979.

SCHUMPETER, J. A. Capitalism, Socialism and Democracy. London: Routledge, 2013.

WENDT, A. Social Theory of International Politics. Cambridge Universtiy Press. 2003.

ZAKARIA, F. The Rise of Illiberal Democracy. Nov/ Dec 1997. Available in: https://

www.foreignaffairs.com/articles/1997-11-01/riseilliberal-democracy Access: 10 July. 2020.

ZEBIRI, K. Orientalist Themes in Contemporary British Islamophobia, In: KALIN I.; ESPOSITO, J. L.

(Org) Islamophobia, The Challenge of Pluralism in the 21st Century. Oxford University Press, 2011. 